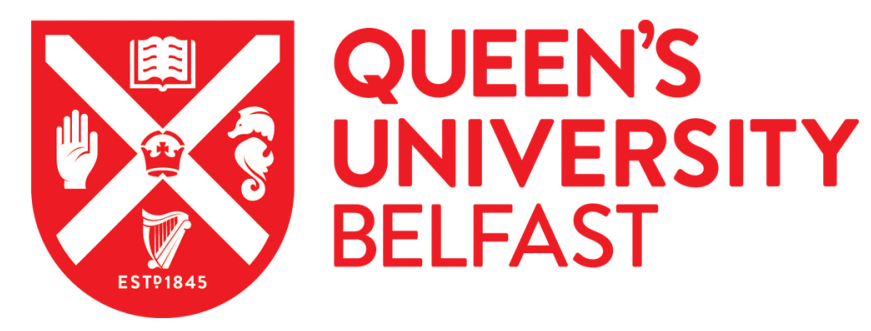

\title{
Are Rights Out of Time? International Human Rights Law, Temporality, and Radical Social Change
}

McNeilly, K. (2019). Are Rights Out of Time? International Human Rights Law, Temporality, and Radical Social Change. Social and Legal Studies, 28(6), 817-838. https://doi.org/10.1177/0964663918815729

\section{Published in:}

Social and Legal Studies

\section{Document Version:}

Peer reviewed version

Queen's University Belfast - Research Portal:

Link to publication record in Queen's University Belfast Research Portal

\section{Publisher rights}

(c) 2018 The Author. This work is made available online in accordance with the publisher's policies. Please refer to any applicable terms of use of the publisher.

\section{General rights}

Copyright for the publications made accessible via the Queen's University Belfast Research Portal is retained by the author(s) and / or other copyright owners and it is a condition of accessing these publications that users recognise and abide by the legal requirements associated with these rights.

Take down policy

The Research Portal is Queen's institutional repository that provides access to Queen's research output. Every effort has been made to ensure that content in the Research Portal does not infringe any person's rights, or applicable UK laws. If you discover content in the Research Portal that you believe breaches copyright or violates any law, please contact openaccess@qub.ac.uk. 


\title{
Are Rights Out of Time? International Human Rights Law, Temporality and Radical Social Change
}

\author{
Kathryn McNeilly ${ }^{1}$
}

\begin{abstract}
Human rights were a defining discourse of the twentieth century. The opening decades of the twenty-first, however, have witnessed increasing claims that the time of this discourse as an emancipatory tool is up. Focusing on international human rights law, I offer a response to these claims. Drawing from Elizabeth Grosz, Drucilla Cornell and Judith Butler, I propose that a productive future for this area of law in facilitating radical social change can be envisaged by considering more closely the relationship between human rights and temporality and by thinking through a conception of rights which is untimely. This involves abandoning commitment to linearity, progression and predictability in understanding international human rights law and its development and viewing such as based on a conception of the future that is unknown and uncontrollable, that does not progressively follow from the present, and that is open to embrace of the new.
\end{abstract}

Key Words: international human rights law, radical social change, law and time, temporality, legal theory, women's rights

\section{INTRODUCTION}

Developments over the latter half of the twentieth century have promoted the perception that we are living in the age, or the time, of human rights (Henkin, 1990; Bobbio, 1996). Human rights have proliferated in law and politics and are a central means of evaluating the past and present, as well as driving progress for the future. This understanding has been advanced by the United Nations (UN) and its ever-expanding catalogue of treaties; the development of regional human rights regimes; the activity of national and international non-governmental organisations; as well as by legislatures and courts across jurisdictions, continents and legal systems. However, some have asked more critical questions about this time of human rights

\footnotetext{
${ }^{1}$ Lecturer, School of Law, Queen’s University Belfast. Email: k.mcneilly@ qub.ac.uk. Tel : (0) +44 289097 3454. I am grateful to Professors Fiona de Londras, Chris McCrudden and John Morison who read and provided insightful comments on earlier drafts of this piece. The piece was also shaped by discussion at the Time(s) and Temporality of International Human Rights Law workshop which took place at Queen's University Belfast in July 2018. I also offer thanks to participants at this event. Any errors remain my own. This article is forthcoming in Social and Legal Studies (2019).
} 
and, specifically, about the future of rights as a politico-legal discourse of social change (Hopgood, 2013; Posner, 2014; Mutua, 2015). The opening years of the twenty-first century have witnessed challenge to the ability of human rights to make a meaningful difference in contemporary contexts of financial collapse, changing patterns of migration, war, and terror, to name a few.

The question accordingly arises, as Upendra Baxi states, 'whether human rights languages will... wither away and what may take their place. Far from being unreal, th[is] question is already heavily posed to us' (2008: xxxv). Those who contest the value of rights in this global landscape declare that human rights are out of time; that their time as an emancipatory vision for the future is up, that they are no longer the discourse of the moment that we are living in. This is an important challenge which is waxing rather than waning, and has significant implications for the everyday work of those who practice, study, write about and teach human rights. Accordingly, this challenge must continue to be responded to. This is what I aim to do in the present article, with a focus on international human rights law. ${ }^{1}$ In doing so, I contribute to the diverse body of scholarship which, while critical, aims to retain some future use for human rights through reimagining their conceptual underpinnings (Lefort, 1986, 239-272; de Sousa Santos, 1997; Douzinas, 2000; Balibar, 2013). In this contribution, I take response to the contemporary challenge to rights in a new direction through conversation with new theoretical resources.

In the following I argue that international human rights law is not out of time, but it should be. By this I do not mean that the time of these rights has come to an end, or that their utility has necessarily faltered. Rather, what I argue is that a productive future for this area of law may be envisaged by considering more closely its relationship to temporality and by actively thinking through a conception of rights that is untimely. I use this term in the sense articulated by Elizabeth Grosz; as that which is out-of-step or out-of-time, which goes beyond a linear and progressive relation between past, present and future and, additionally, involves a,

'leap into the future without adequate preparation in the present... a movement of becoming-more and becoming-other, which involves the orientation to the creation of the new, to an unknown future, what is no longer recognizable in terms of the present' (Grosz, 2010: 49).

Untimeliness thought in this way requires abandoning commitment to linearity, progression and predictability in understanding international human rights. In contrast, this area of law must 
be apprehended as operating via a conception of the future that does not necessarily follow progressively from the past or present, that is unknown and out of control of the present, and that better foregrounds the continual elaboration of the new. Reconsidered as untimely concepts, international human rights are always orientated towards the future. A futural-focus for rights is one which has indeed been imagined by existing work re-evaluating rights (Douzinas, 2000; McNeilly, 2017; Kapur, 2018). However, untimeliness embeds a particular futurity at the heart of rights: the future they offer is not knowable - outlined in relevant declarations, treaties and other instruments - nor progressively following from the present. In contrast, it is one that cannot be known in advance. While this contains significant risk and uncertainty, it also enhances the possibility for international human rights law to be used for radical social change - defined as a transformation of social structures facilitating inequality on grounds such as race, gender and class - through stimulating radical democratic debate on current relations of living and being which embraces newness and alternative directions for social life. To bring this understanding into being I suggest that useful resources can be found in the work of Elizabeth Grosz, Drucilla Cornell, and Judith Butler. The rich work of these scholars, connected by a common concern with time, has much to offer reflections on an untimely future for human rights in their international legal form and can assist in furthering critical work responding to the challenge mounted against rights today.

My argument proceeds in three parts. In the first I explore dominant approaches to time in international human rights law. I draw attention to the linearity and progression between past, present and a knowable future which can be detected in prevailing ways of understanding this area of law. In the second part I move to outline my proposal of a contrasting untimely conception of international human rights law informed by the work of Grosz, Cornell and Butler. As part of thinking this through, I reconsider the developmental narrative of international human rights law as untimely, drawing on Grosz's reading of Charles Darwin. In the final part I investigate the tangible possibilities of such a conception in relation to one field where a recent impasse has led the contemporary utility of international human rights law to be questioned: that of women's rights.

\section{THE TIME OF INTERNATIONAL HUMAN RIGHTS LAW}

A significant amount has been written on the time of human rights in both its possible conceptions - the idea that we are living in an era of human rights; and the connection between human rights and wider ideas of time and temporality. In this section I focus on the latter as an 
introduction to the untimely approach to rights that I am advancing. The relationship between human rights and time has been thought in various ways, only some of which are overtly labelled as such. For example, scholars have reflected on the connection between human rights and memory or memorial discourses (Levy and Sznaider, 2010; Huyssen, 2011). A canon of work exists on the role of human rights in periods where time is interrupted, including human rights and transitional justice (Collins, 2010; Buyse and Hamilton, 2011). Human rights have also been conceived of as deeply connected to the past and as using past resources for the present; genealogies connecting human rights to the thought of earlier civilisations and times (Ishay, 2004).

Turning to international human rights law, the legal character of these rights renders it essential to also consider the relationship between law and temporality (French, 2001; Tur, 2002; Khan, 2009). Law can be thought to do more than exist in time, but actually serves to construct ideas of time (Greenhouse, 1989; Grabham, 2016). As a discursive practice, law sustains competing temporalities: beginning in time as a human product but also having no firm beginning or end point; being certain and enduring from enactment but simultaneously reversible (Greenhouse, 1989: 1638-1644; Bloom, 2015). Law advances Western, linear conceptions of time but also temporalities which are cyclical, backwards moving and beyond linearity (French, 2001: 671). This is demonstrated in the common law doctrine of precedent which commits to a linear predictability but also holds an ability, should present circumstances require, to be overturned (Greenhouse, 1989: 1640; Tur, 2001).

As with other forms of law, international human rights law demonstrates a complex and multitudinous connection to time. The dating and coming into force of treaties in linear time sits alongside periods of cyclical state monitoring; a strong sense of origin accompanies ideas of international human rights as timeless; subjective experiences of time from the perspectives of individual victims of rights violations coexist with a corporate conception of time advanced by the international human rights law project more generally. However, despite these underpinning rival constructions of time, a definite linearity dominates how this area of law is understood and narrated. ${ }^{2}$ This can be detected in a range of locations. As an example, one important area evidencing commitment to a linear connection between rights, the past, present and the future is philosophical thinking on the 'what' and 'why' of international human rights law. This dominant linearity, furthermore, is coupled with a conception of a future that is predictable or knowable. Let us consider this further.

While many perspectives exist in this area (Langlois, 2004), two leading approaches to understanding and justifying human rights have emerged in political philosophy. The first 
begins with the practice of rights. These approaches are termed 'practice-dependent'. Under this umbrella are the 'political' accounts of John Rawls (2002), Joseph Raz (2010) and Charles Beitz (2009). The second dominant way of understanding human rights comes from 'practiceindependent' accounts. These view human rights, generally speaking, as based on a priori reasoning. Human rights in international law, in this view, can be traced back to an idea of rights generated by moral theory. Scholars in this tradition include John Tasioulas (2012) and James Griffin (2008).

Starting with the former, practice-dependent scholars understand international human rights vis-à-vis their political function, or what they are being used to do. In this account, human rights are created by states operating within an international politico-legal regime and cannot exist outside such. Beitz, for example, is highly critical of accounts which see an a priori basis for human rights, stating instead that the authors of the international human rights doctrine 'disowned the thought that human rights are the expression of any single conception of human nature or good' (2009: 8). In contrast, Beitz conceives international human rights law as an 'emergent practice' post-World War II, consisting of a set of norms for the regulation of government conduct (2009: 14). A distinctive temporality underpins this work. Explicitly rejecting international human rights norms as timeless protections transcending time and place, Beitz points instead to the modern context for international human rights law (2009: 31). International human rights law, in this practice-based view, evidences a commitment to linearity. Based on the experiences of the recent past - the horrors of World War II - states came together to establish norms which expressed 'a common standard of aspiration' (Beitz, 2008: 22) for a better future and which could be drawn upon to bring such a future into being. This demonstrates a progressive relationship between the past, present and future: international human rights law is understood as a practice emerging to bridge the past and future in the specific mid-twentieth century period.

The second ontological approach - practice-independent accounts - sees human rights as not defined by their practice or political function, but as grounded in our humanity: as rights we have in virtue of being human. These rights stem from moral rights which have developed in many ways since their origins in early natural law, including through positive enactment in international law. In this perspective, human rights exist to protect essential human interests. There are many ways of articulating what these essential interests are. One approach is advanced by Griffin who conceptualises human rights as protections of our personhood (2008: 33). Human rights, for Griffin, protect human dignity and, in particular, our normative agency as human beings (Griffin, 2008: 2). A right can be established on this account by showing, first, 
that it protects an essential feature of human standing and, second, that its content results from practical considerations (Griffin, 2008: 44). Similar to practice-dependent approaches, accounts such as Griffin's also demonstrate an implicit commitment to a linear temporality. Human rights for these scholars serve to proclaim a timeless truth about the moral centre of humankind. The aim of rights is to progressively work towards the securement of the human virtue at hand. In Griffin's view, for example, the human agent is the pinnacle of moral achievement and upholding the agentic human subject is the goal which must be pursued. Human rights in international law may be inferred as one vehicle for this - tools for the achievement of a futural, complete protection of essential human interests which offers better protection than in the past and present. While human normative agency is currently inadequately protected, human rights offer a way towards better protection in the future.

Both these perspectives, therefore, commit to a linear connection between past, present and future. These theories also share a second characteristic which follows from the first. The future they point towards is predictable and knowable in the present: taking the form of a society where specific rights content is realised. For example, in his analysis, Beitz urges us to understand international human rights as constitutive norms of a global practice aiming to protect individuals from their governments. The future which this practice envisages has a blueprint in existing international human rights law provision pertaining to matters which are within the scope of legitimate international concern (Beitz, 2009: 197). In contrast, Griffin's conception of human rights as protections of normative human agency leads him to generate a list of key rights which includes departure from international human rights law as it currently stands (2008: 149-188). While differing in content and form, both dominant ontological accounts understand human rights as leading towards a predictable future, specific rights content creating a future horizon for human rights action in the present.

Accordingly, a linear temporality towards a knowable future has characterised understandings of the 'what' and 'why' of this area of law. To answer the charge that international human rights law no longer has any purchase, I argue that it is necessary to revisit such. Recall, as outlined above, that this law sustains multiple temporalities; cyclicality and timelessness, for example, as well as linearity. Following from this, it is possible that alternative temporal movements may be engaged to conceptualise the relation between past, present and future in international human rights law and, resultantly, how these rights are understood and what they are capable of offering. Here is where the assertion that human rights are out of time, while not to be agreed with in the sense of disregarding a use for rights, does offer a useful starting point for those interested in reimagining and redeploying these normative 
ideas. It inadvertently suggests a need to rethink the connection between international human rights law and temporality beyond conceptions of time which are dominant. This is a move which has not yet been fully explored, building on, but going further than, work considering new ideas of futurity for rights or reassessing their temporal logic in relation to pasts, transitions and beginnings (Douzinas, 2000; Meister, 2011).

Such would involve repositioning the relationship between human rights and futurity from a tendency towards a predictable, knowable future progressively following from the past to a conception of the future that is unknown, non-linear, and more open to embrace of the new. Through this, enhanced possibilities for radical social change in the present may be offered. This is because embrace of the new - that which is unexpected, unpredictable and unknown holds potential to stimulate attention to previously invisible relations of exclusion or ways of structuring society that differ to those currently perpetuating inequality, for example. This assertion carries a democratic impetus which, I suggest, can be linked to work with radical democratic leanings, including that of Ernesto Laclau and Chantal Mouffe (2001), Judith Butler (Butler, Laclau and Žižek, 2000), and Jacques Rancière (2004). In different ways, such work draws attention to the power of new voices, perspectives and that which is currently excluded to challenge the limits of dominant discourses through their revelation in ongoing democratic dialogue and debate. Human rights have been thought as offering a vehicle through which such debate can take place (Chambers, 2004; McNeilly, 2016). This possibility is enhanced when these politico-legal norms are conceived as driven by a temporality that is beyond linearity and predictability. While it is of course not guaranteed that attention to the new facilitated by a nonlinear and unknown future will in all instances facilitate successful democratic debate on social change, or change that is specifically radical, greater possibilities for such are offered by this approach. In the present context where human rights appear inherently caught up with the time and rhythms of neoliberalism internationally (Moyn, 2018), this appears a risk which is worth taking. How I advance that such possibilities can be facilitated is by bringing international human rights law into conversation with alternative resources and ideas of time and, specifically, by thinking such rights as untimely.

\section{RIGHTS OUT OF TIME: TOWARDS AN UNTIMELY CONCEPTION OF INTERNATIONAL HUMAN RIGHTS LAW}

\section{Beginning to Think International Human Rights Law as Untimely}


While not always overtly acknowledged, international human rights law already demonstrates a temporal fitfulness which is out of time. This is evident in its working at times in linearity or predictable flow - as noted above, the dating of treaties and cyclical state monitoring are examples of such - but at others working to arrest a temporal flow (Johns, 2016: 50-55). The latter is demonstrable, for instance, in outlining timeless obligations while simultaneously facilitating emergency derogation from them in particular presents, or allowing for irregular instances of state monitoring via individual complaint mechanisms. Untimeliness, in this respect, is one of the multiple temporalities co-existing in and co-created by this area of law. My advancement of an untimely conception of international human rights law builds upon this observation, but takes the idea of untimeliness further, using it as a tool to reconsider what international human rights are and may be used to achieve at a basic level. To do so, I propose turning to the work of three feminist thinkers: Elizabeth Grosz, Drucilla Cornell and Judith Butler. ${ }^{3}$ While diverse in their focus, influences, and often overarching assertions, ${ }^{4}$ all three may be read as united in their attention to time and temporality. This is undoubtedly most conscious and sustained in the work of Grosz, but, as I will explore, Cornell and Butler too undertake significant engagements with temporality. Considered alongside one another, these scholars can be positioned to offer useful resources for re-approaching the relationship between international human rights and time.

In her interconnected works The Nick of Time (2004) and Time Travels (2005), Grosz dedicates attention to the question of time, exploring, in her words, 'the implications and effects of conceiving a temporality in which the future remains virtual and beyond the control of the present' (2005: 1). In doing so, her aim is to outline,

'a concept of temporality not under the domination or privilege of the present, that
is, a temporality directed to a future that is unattainable and unknowable in the
present, and overwrites and redirects the present in an indeterminacy that also
inhabits and transforms our understanding of the privilege of the present. (Grosz, 2005: 1)

Grosz advances a conception of untimeliness which is informed, primarily, by the thought of Friedrich Nietzsche and Henri Bergson. ${ }^{5}$ Untimeliness in this reading is foregrounded by jettisoning the force of the present and instead embracing an unknown future which is fitting with a conception of life as an ongoing becoming. Subsequently, any construction of linearity, and any sense of progress or predictability, must be abandoned in favour of the "pre-eminence 
of an undetermined future' (Grosz, 2002: 15). Here futurity takes on a specific form: it is out of control of the present, often a surprise. We cannot predict the future or seek mastery over it, but, rather, must succumb to the unpredictable rhythms of time, to newness and contingency. ${ }^{6}$

This approach is highly relevant for law and politico-legal activity. Contrary to many ways of thinking about law, including international human rights law, it suggests that it is not strictly possible to learn from the past for the future in a substantive sense. Time must be considered as the continual elaboration of the new; the openness of things to what befalls them (Grosz, 2005: 110). The aim of any politico-legal activity seeking radical social change, therefore, must not be to predict or contain the future or to conceive of a progressive connection between past, present and future, but to be open to and induce the untimely (Grosz, 2004: 14). This means giving up the presumption that the future follows straightforwardly from the past, and resisting setting agendas for a knowable future in favour of embracing newness and the possibilities that this may bring. Grosz comments that 'the more clearly we understand our temporal location as beings who straddle the past and the future without the security of a stable and abiding present, the more mobile our possibilities are, and the more transformation becomes conceivable' (2004: 14). To provide an example, this might mean departing from an understanding of human rights as legal tools which may be employed post-conflict, disaster or uprising to implement lessons for a future which is knowable in advance. Instead, human rights might better be seen in such situations as tools to facilitate ongoing democratic debate on futures that are informed by but not constrained by the past, that are not predictable in the present, and that are inherently open to unexpected voices and directions. Accordingly, this conception of temporality offers rich resources to think about law ${ }^{7}$ and politics - positioning such beyond linearity, predictability and mastery - and how such activities may be orientated towards radical social change by meaningful opening such up to the unpredictable and the new.

On the point of social change, it is useful to turn to Cornell and Butler who are both concerned with transformation of existing structures and relations of power, primarily (though not exclusively) those related to sex/gender. What I wish to draw from here is not their arguments regarding sex/gender, ${ }^{8}$ but their respective comments on radical social change and temporality. While neither substantively draws upon Grosz, nor indeed overtly labels their discussion as pertaining to temporality, each deploys a conception of social change that is located in a future which is unknowable, non-linear and demonstrates similarities to Grosz's untimely approach. In Cornell's corpus, an impetus towards social transformation is an unmissable theme (Cornell, 1993; 1995). For Cornell, a significant element of such is challenge to gender hierarchy and, following Luce Irigaray (1985), the affirmation of 'the feminine' 
within sexual difference. Cornell sees the feminine as never having been truly realised in an emancipatory form, it remains a 'not yet' (1993: 98). A future feminine which breaks from the past and provides wider, unpredictable possibilities for women's lives is essential to social transformation for Cornell. These possibilities, drawing from Jacques Derrida (1976), are already existing and exploitable in the present which can always be otherwise (Cornell, 1999: 169). This underlying attention to temporality has been reflected on by Grosz who describes Cornell as seeing 'the future neither as irrelevant nor as directly manipulable, neither as the realization of current wishes or fears... nor as simply speculative, utopian, impossible', rather the future appears as 'the very condition and very mode of present political, ethical, and legal action and effectivity' (Grosz, 2005: 72). From this, Grosz endorses in Cornell an urge that 'we must act in the present, with the light the past sheds on that present, but we must, by virtue of the difference that inhabits the present, cede any control of our present act to a future that we cannot foresee or understand' (Grosz, 2005: 75).

Butler too is attentive to the connection between futurity and transformation, albeit also in an implicit manner. In Butler's thought, it is possible to find resources to implement an openness to the untimely. Butler explores how terms such as 'the subject', 'man' and 'woman' are 'never finally and fully tethered to a single use' (2004: 179). Such terms, while often problematic in that they may be exclusive in their current form, can be opened to new futures. The past and present of these terms can be disrupted in unexpected and non-linear ways by reiterating what they mean anew. 'Woman' and 'man' might be re-approached as fluid identities encompassing unexpected possibilities beyond their current understandings. For Butler, it is this activity that holds potential for radical social change. As she states,

\footnotetext{
'the term would then open up a different temporality for the polity, establishing for that polity an unknown future, provoking anxiety in those who seek to patrol its conventional boundaries. If there can be a modernity without foundationalism, then it will be one in which the key terms of its operation are not fully secured in advance, one that assumes a futural form for politics that cannot be fully anticipated' (Butler,
} 2004: 180).

In opening terms to unsettlement and uncertain futures through ongoing reiteration, a wider future-focused democratic politics can be stimulated which facilitates social change by being open to new forms, shapes or directions for social life. This vision of politics always looking to the future, debating its shape and form in an ongoing way, is a particularly useful element 
of Butler's work, offering some idea further than Cornell of how an orientation to an unknown future might be initiated. ${ }^{9}$

While there are disparities between Grosz, Cornell and Butler, a key commonality emerges. All three urge us to act in the present - informed but not constrained by or emerging progressively from the past - for an uncertain and uncontrollable future, and perceive radical social change as achievable through a conception of life, politics and, indeed, law as ongoing, uncontainable becomings outside linearity and predictability. This proposition, emerging in different ways from the work above, can be brought to the thinking and practice of international human rights law to stimulate a new approach to this discourse for the contemporary period. These rights can only be of use if they are conceived not as concepts drawn upon in the present for a predictable and linear future, but as untimely politico-legal concepts orientated towards a future which, like human life itself, is endlessly becoming. This becoming is always beyond control, characterised by a continual elaboration of the new and openness to what may come in the context of democratic politics. Such an understanding unsettles what we know about human rights and, in turn, rights conceived as such offer more meaningful utility - but, of course, not certainty - to facilitate radical social change. It is only through opening up to the unknown and its uncertainties that, as Butler and Cornell assist us to see, productive democratic debate on social change can have any possibility of occurring. Engaging such in the context of international human rights law may allow us to move beyond what has been described as the apolitical future-focus of international human rights in recent decades (Moyn, 2014: 135-148) to imagine a future in and for such rights that facilitates democratic debate on the new and the excluded, refocusing on what is political, oppositional and contestatory at the heart of rights (Douzinas, 2007: 101-110).

Following this line of thought, international human rights law can still offer hope for the future, but not in the same way as has been perceived throughout the twentieth century. The futural possibilities of this discourse are not located in a set of treaty provisions which determine a knowable, ideal future to measure the present by or progress towards, but in the potential for rights to open us, and their own meanings, to the unknown, the new and the unpredictable. In a grounded sense, this means that international human rights law becomes less about laying down legal obligations and pursuing ever-increasing state adherence to such, and more about embracing how the law and politics of rights can uncover the unexpected and help usefully break with the past or present. While this assertion stems from theory, it has profoundly practical implications. It stimulates a modified way to understand international 
human rights law and its everyday engagement. Let us consider this further, reflecting on what it might mean to bring this idea of untimeliness to this area of law.

\section{The Development of International Human Rights Law as Untimely Evolution}

Embracing international human rights law as untimely requires a return to the basics of how these rights are conceived. This work will have many facets, all of which cannot be considered here. However, a productive place to begin is by re-approaching the developmental narrative of this discourse; how human rights in international law are understood as concepts which have developed, and which continue to do so. Despite the blossoming of diverse historiographies (McCrudden, 2015), the developmental nature of international human rights has not been considered as untimely in the manner discussed above. To begin this task, it is productive to remain with Grosz. In particular, turning to her untimely interpretation of Charles Darwin to advance international human rights as, at their heart, untimely evolutionary concepts.

Central to Grosz's thoughts on temporality in The Nick of Time and Time Travels is a re-engagement with Darwinian evolution by natural selection (Darwin, 1989; 1901; 1909). For Grosz, the resonances of this idea remain to be properly understood, especially its potential to provide 'theoretical models, methods, questions, frameworks or insights that nevertheless, in spite of their recognizable limitations, could be of some use in understanding and transforming the prevailing structures of (patriarchal) power' $(2005: 17) .{ }^{10}$ It is not possible to capture the full complexity of Darwin's thinking here. It is necessary, however, to provide some outline of his work before progressing to Grosz's reading of it. Briefly put, in what has become known as his conception of evolution, Darwin stressed three elements: variation, inheritance, and selection. Darwin sought to demonstrate how current species are descended from earlier forms of themselves - rendering there no 'origin' per se, only repetition with difference through heritable variation - and how this kind of evolutionary transformability, an ongoing 'descent with modification' (Darwin, 1909: 132), occurs via a process of natural selection. In this process, organisms multiply at a pace that exceeds the capacity of the environment, meaning that some must perish or fail to successfully reproduce. An organism can be regarded as adapted to its conditions of life if its inherited variations allow it to survive in the given environmental context. This process of adaptive change continues without necessary direction or limit.

Grosz makes visible the tools that can be discerned from this account. She reads Darwin as providing, 
'an ingenious temporal machine for the production of the new, which constrains the new only through the history that made it possible and the present which it actively transforms, but which leaves its directions, parameters, and destinations unknown and unknowable' (Grosz, 2004: 25).

Darwin's work can be grasped as defined by elements that are compatible with Grosz's understanding of time. As she comments,

'evolution is a fundamentally open-ended system which pushes toward a future with no real direction, no promise of any particular result, no guarantee of progress or improvement, but with every indication of inherent proliferation and transformation' (Grosz, 2004: 26).

Darwin's approach to the natural world provides an account of endless variation and difference towards a future which is not constrained by the past, although informed by it, that is inherently unpredictable and eschews the notion of progress (Howard, 2001: 92-102). Here time is not linear, but deep and vast, an almost limitless reservoir where innumerable variations can play out. The underpinnings of this approach, therefore, hold potential to foreground temporal dispersion, movements and processes rather than linear development, goals and ends and the future as an opening up of the present to ongoing variation and becoming (Grosz, 2004: 30).

What relevance might this reading of Darwin have for discussion of international human rights law and its development? In Grosz's re-engagement with Darwin's work, I suggest that a distinctively untimely approach to evolution as a broad practice or concept emerges. The overarching principles of Darwinian evolution - read via Grosz as stressing temporal dispersion, variation and an unknown future - are useful in thinking about the developmental narrative of international human rights law. It is important to stress that a wholesale or straightforward 'application' of Darwin is not being proposed here. A social Darwinist account applying his conception of natural or biological life to the normative domain of international human rights law is not what I am aiming for (Hawkins, 1997). Rather, I suggest that some of Darwin's underpinning principles, thought in a Groszian manner as demonstrating untimely evolution, can be reformulated and deployed to bring a new perspective to this area. This is an extension of Darwinian tools to the development of human rights which has not been undertaken to date, ${ }^{11}$ but offers a productive means to reconsider this 
area of law and its relation to time and, from this, its potential to facilitate radical social change in the present.

A starting point in understanding human rights in international law as untimely, evolutionary concepts can be found by considering the idea of variation central to Darwinian evolution. The importance of perceiving current species as produced through variation, as opposed to having a fixed origin, can also be brought to reflection on international human rights law to reframe its developmental trajectory. Rather than aiming to locate an 'origin'- be this the 1940s post-War period or some other point in history - this politico-legal discourse can be embraced as having, at a basic level, no origin. Let me be clear: this does not mean that international human rights law emerged from nowhere. Quite the opposite, it means that such has come into being through a long process of repetition and variation in contingent contexts. These contexts shape the future for rights, albeit the future remains unknown and is not constrained by the past or present. In this variation, some forms of rights will perish, while others will demonstrate a useful variation allowing them to flourish. This is evidenced in the fact that some variations of rights became codified in international law in liberal democratic, capitalist settings - namely, those shaped by classical liberal thinking - while others - for example, communal conceptions of rights asserted by thinkers such as Gerrard Winstanley (2009) - did not.

Contingent historical contexts set goals, provide resources and incentives for particular understandings of rights to succeed. This process continues in the present period as current contexts, such as neoliberalism and existing relations of racial, gender and other power, inform the possibilities for human rights and their evolutionary shifting. But, the future for rights still cannot be known. In this view, the development of international human rights can be understood as one of descent with modification whereby rights ideas are reproduced and adaptively change in prevailing socio-legal and political landscapes in an ongoing and unpredictable way. In this process just as there is no origin, there is also no end point. Human rights can never be viewed in terms of linear progress towards a final achievement. The untimeliness inherent in Darwin's evolution assists us to view development as always ongoing - a long-term activity - but not in the sense of progressing, guided to a significant extent by contexts, contingency and chance rather than controlled by states, the UN, international lobbyists, non-governmental organisations, or others towards a final end or goal.

On first blush, this approach may appear uncontroversial. It is difficult to find an international human rights scholar or practitioner who would refute that these rights are open to change and have demonstrated ebb and flow. The language of evolution is common across 
scholarship reflecting on the history of human rights law (Bates, 2010; Burke, 2010; Lauren, 2011). However, existing accounts of evolutionary development do not quite grasp the approach to, or the consequences for, rights and their relationship to time that I am trying to foreground. While this literature may agree that human rights have evolved in a responsive way to the present point, and not necessarily via straightforward progress, this does not fully amount to the same thing as that outlined above. Understanding the evolutionary nature of international human rights law using untimely Darwinian principles allows something more to be brought into view: this approach facilitates an alternative account of the relationship between futurity and human rights.

Following Grosz, Darwin's evolution can be read as underpinned by a particular temporality - one of ongoing becoming in the present which is towards a future that is unknown and does not follow progressively from the past. As noted above, Darwin fundamentally rejects progress as a driving force. Evolution, rather, is a blind process, at times moving forwards, at others appearing to move backwards (Howard, 2001: 98-100). In this approach to variation and adaptive change, as Grosz elaborates, 'beings are impelled forward to a future that is unknowable, and relatively uncontained by the past: they are directed into a future for which they cannot prepare' (Grosz, 2004: 29). The futurity of international human rights law as an evolutionary discourse thought in this manner is accordingly one of ongoing striving in the present for a future that is informed by the past but not tied to it. Rights emerge via a conception of the future which is, and must remain, unsettled and unknowable, capable of moving forwards, backwards or in another direction in response to contingent contexts. This form of law must be approached as a never-ending process whose development is out of control of the present, a process of unpredictable movement in patterns of repetition and variation responding to the new. Viewing international human rights law as evolving in a Darwinian sense, therefore, opens up possibility to think the relationship between rights and futurity beyond linearity and a knowable future and towards untimeliness in a way that other evolutionary accounts do not.

This change is significant. Whilst such a conception of course brings risk and opens opportunity for critics to say that international human rights offer no certain utility or vision, it equally performs the opposite, holding a productive future for this area of law. It is here where human rights actors committed to the often comforting narrative of linear progress may be reassured. This productive future is contained in the fact that as always unsettled, driven by contingency and the new, these rights hold the ability to point towards a future in socio-political life more generally which is equally unsettled and unconstrained by the past, to challenge what 
we think we know about the present, and to orientate ourselves towards different futures compatible with radical social change. As Grosz states,

\begin{abstract}
'Darwin presents in quite developed if not entirely explicit form the elements of an account for the place of futurity, the direction forward as the opening up, diversification, or bifurcation of the latencies of the present, which provide a kind of ballast for the induction of a future different but not detached from the past and present' (2005: 30).
\end{abstract}

By embracing the out-of-time, the unexpected and the new, alternative directions for social life may emerge. International human rights are untimely in that they are shaped by uncontainable evolutionary descent with modification responding to the new, and through this can direct towards a broader future that is unknowable, rather than predictability and progression, towards productive processes of transformation and change rather than an exclusive search for legal solutions.

Further explanation of how this is possible can be explored by recalling the work of Butler and Cornell. Both stress that social transformation can only occur via a conception of time as open to unpredictability, loosening us from the past towards an unknown future. For Cornell, change to current, restrictive relations of sexual difference is located in the feminine having a futural and untimely character (Cornell, 1993: 98). To facilitate change to how we understand sexual difference the feminine must be thought of as yet-to-come, an unpredictable form of living and being sexual difference which does not resemble that of the past. Similarly, Butler sees change to currently restrictive conceptions of terms such as 'the subject', 'man' and 'woman' as occurring through opening such to new futures transcending their past and present, debating anew what and who they may encompass. For both these authors, it is through exposing taken for granted ideas to new, unexpected usages which may break with the past that radical social change can happen. When the historic, and ongoing, development of international human rights law is viewed through the lens of untimeliness, rights become capable of facilitating such. They may direct towards a future that is unknowable, always becoming and not tied to linear time. Drawing from Butler specifically, rights thought as evolving in an untimely way may be capable of use to stimulate a future-focused politics of never-ending democratic debate on alternative, unpredictable futures. It is in this manner that an untimely conception of human rights may help facilitate an orientation to life, politics and the social which is equally untimely and open to the new. 
It is important to pause here and note that a move towards untimeliness in how we understand the evolution of international human rights law is not advanced as promoting a progressive narrative for this discourse and its connection to social emancipation. It is not the case that embraced as untimely rights will continue, or begin, a forward-pushing evolutionary trajectory inevitably facilitating contestation of power and a more equal shaping of social life. Untimely evolution may involve what might be perceived as regressive as well as progressive movements for international human rights law and politics. While potentially anxietyprovoking, this is to be understood as part of the ongoing, messy development of rights. Instead, what an untimely approach to evolution is advanced as offering is a potential starting point for political actors and groups to reimagine and re-engage international human rights law more focused on the new, thereby opening an alternative to abandoning such rights in the contemporary period. This potential is not a guarantee, but offers hopeful possibility. In thinking further about what such an approach to rights evolution might look like and offer, it is useful to turn to a tangible example. Below I reflect on one field of international human rights law which appears to have reached somewhat of an impasse and consider how it may be approached in an untimely manner: that of women's rights.

\section{A FUTURE FOR WOMEN'S INTERNATIONAL HUMAN RIGHTS OUT OF TIME}

A substantial range of international human rights treaty provision, jurisprudence and soft law material is dedicated to a concern with the everyday experiences of women. ${ }^{12}$ From the outset effort was made to integrate such into this area of law. In the 1940s the Commission on the Status of Women ensured inclusion of prohibition of discrimination on the basis of sex in the Universal Declaration of Human Rights (Morsink, 1999: 116-129). The Commission was subsequently instrumental in drafting the 1979 Convention on the Elimination of All Forms of Discrimination Against Women (CEDAW). This was highly significant work. However, from the 1980s onwards, scholars such as Hilary Charlesworth (1995), Rebecca Cook (1993), Christine Chinkin (1999) and Charlotte Bunch (1990) argued that in its practice, provisions and structures of international human rights law did not adequately respond to women's lives, but was in fact based on a male subject and the fears or concerns of this subject (Charlesworth, Chinkin and Wright, 1991: 622). The result was a global campaign, uniting scholars and practitioners under the slogan 'Women's Rights Are Human Rights'. This campaign extended throughout the 1980s-90s and successfully secured new rights protections in areas such as 
violence against women, sexual violence during conflict, and reproductive health (Bunch and Fried, 1996).

In the opening decades of the twenty-first century, on the one hand, international human rights law remains a key site for advancing the needs of women. On the other, however, a new critique has materialised questioning the continuing utility of the 'Women's Rights Are Human Rights' approach. This critique has focused on the binarised and asymmetrical understanding of sex/gender (i.e. male/female and male>female) characterizing women's rights. Following the work of scholars such as Butler (1990), sex/gender can be understood as not binarised, but fluid - existing on a spectrum - and encompassing a range of power relations inclusive of, but extending beyond, the male>female asymmetry alone. This approach seeks to better recognise the diversity of sex/gender identities. It encompasses those of 'masculine' female identity or 'feminine' male identity, lesbian, gay, bisexual, trans* and intersex persons, and those who identify as having a fluid gender identity. Through this approach it is possible to highlight the rights needs of more people, including women, and to rethink the limits of terms such as 'woman', 'man' and 'gender'. As Dianne Otto observes, there has been a reluctance in international human rights law,

\footnotetext{
'to fully pursue the opportunities opened by this new understanding of sex/gender and, in particular, [a] failure to question the male/female dualism and biological base of sex/gender orthodoxy, and [a] related unwillingness to address gendered discrimination suffered by men and other genders, often including transgendered women' (Otto, 2015: 300).
}

Such is evident in, for example, championing of the right to non-discrimination on the basis of sex and development of protections related to violence against women during the 1980s-90s. Both understand sex/gender in a binarised and asymmetrical way which hinders understandings of gender as affecting multiple persons in various relations beyond just male>female. The critique of scholars such as Otto is powerful in highlighting the underlying commitments of the 'Women's Rights Are Human Rights' approach which cannot meaningfully address the complexity of contemporary experiences of sex/gender for women and others.

Resultantly, an impasse can be observed. Before deeming rights out of time in this area, I argue that a conception of international human rights as untimely evolutionary becomings can offer tools to give rights renewed purchase regarding radical sex/gender change. Untimely evolution offers a way to reimagine such rights more focused on the new, and to action current 
critique of women's rights by placing it within a wider reconceptualisation of the developmental narrative of this area. There are two elements to this. Firstly, it is necessary to discard any sense of progress or linearity. This requires rethinking the familiar chronology of women's rights. Rather than a story of progressive realisation from the 1940s onwards, the development of international human rights pertaining to sex/gender should be understood as a process of never-ending repetition and variation responding to contingent contexts and not necessarily moving progressively between past, present and future. Following untimely Darwinian principles, the ongoing descent with modification of this discourse is a blind process and may move 'forwards' as well as 'backwards'. Embracing such means understanding that future development in this area may in fact involve going backwards in order to go forwards. This could entail a return to what is taken for granted by the terms 'woman', 'man', 'sex' and 'gender'. It might also include a return to the foundational labelling of this discourse: moving from 'women's rights' to a more inclusive idea of 'sex/gender' rights, for example. There is, of course, no guarantee that such reinterpretations will succeed in given contextual contingencies, or will be radical as opposed to conservative. ${ }^{13}$ However, integration of more complex understandings of sex/gender at the international level, albeit slowly, suggests that historic context may be changing to offer space for understandings beyond binarisation and asymmetry (Hellum, 2017; Otto, 2018). Furthermore, embracing women's rights as an ongoing, non-linear process of repetition and variation also enables us to see that there is no end point for this work. Openness to contingency and the new means that such rights should be embraced as always unfinished concepts open to further development, this includes their link to ideas of sex/gender.

Secondly, building on this, an untimely approach requires reconsideration of predictability regarding the futurity of rights discourse pertaining to sex/gender to embrace the unknown. This includes understanding that, following Darwin, in evolutionary development the future for such rights is informed by the past and present but never constrained by them. It is never possible to predict or contain the future direction for the relationship between rights and sex/gender, and this should be embraced as positive, offering space to respond to contingency, the new and the excluded. As noted above, this unknown future at the heart of the untimely evolution of rights is also of use because it allows rights to point political actors and groups towards a future in and for socio-political life more generally which is equally unsettled and unconstrained by the past. This holds particular potential when we think of the future of sex/gender. 
Throughout the history of such rights, international human rights law is often conceived of as useful because it offers a knowable future where women and men are equal, where discrimination, violence and other harm on the basis of sex is eradicated. A definitive example of this is found in CEDAW. In its preamble CEDAW notes, affirms, emphasizes and recalls a number of things which characterise state obligations, the discrimination that women face, and the benefits that will accrue from full valuing and participation of women alongside men. For example, one such statement recalls,

'that discrimination against women violates the principles of equality of rights and respect for human dignity, is an obstacle to the participation of women, on equal terms with men in the political, social, economic and cultural life of their countries, hampers the growth of the prosperity of society and the family and makes more difficult the full development of the potentialities of women...' (CEDAW, Preamble).

This constructs the vision of the future which CEDAW promises: one where men and women (binarised and asymmetrical) are equal and human dignity and prosperity are thus fully realised. Following the critique above, however, this vision is in fact of limited use, constraining what (and who) may be recognised as a sexed/gendered subject and rendering international human rights law incapable of grappling with the real challenges of sex/gender in the present (Otto, 2015: 302-303). While a predictable future limited to equality between men and women can be understood as problematic, untimeliness may offer an alternative. It is here where embrace of the unknown is important.

A range of scholarship has sought to re-engage CEDAW to integrate a more nonbinarised and fluid approach to sex/gender identity into this treaty (Rosenblum, 2011; Holtman and Post, 2015; Otto, 2015). Embracing an unknown future via women's rights, however, would take this work further. It would point towards women's rights, and CEDAW in particular, as being about facilitating never-ending democratic debate on unpredictable and unsettled sexed/gendered futures as opposed to using rights to work towards a future for sexed/gendered life which is predictable - even in a non-binarised and fluid sense - and, accordingly, incapable of stimulating attention to the new. In this approach, debate on the terms 'sex' and 'gender' would resist settlement, always having a future meaning which remains contingent and uncontrollable. This reconsideration of the futurity of CEDAW aims to rethink the very underpinnings of this discourse towards productive unexpected and unsettled futures which 
enable the same for understanding of sex/gender more widely. This builds on the earlier work of Rosenblum, Holtman and Post, and Otto: channeling an urging for an expanded approach to sex/gender identity in CEDAW into a wider future-focused politics of the kind that Butler urges towards.

It is not possible, therefore, to provide an exact answer to where women's rights will go from here by employing an untimely approach - the above has explored one potential direction of interest to those committed to radical (re)understandings of sex/gender - but this is the very point. The future of women's rights cannot be controlled, much depends on chance, contingency and context. However, this does not mean that all is lost. An untimely conception of international human rights law grounded in Darwinian evolutionary principles - read via Grosz - offers tools to move from linear progress to variation and repetition which oscillates beyond a linear chronology; from knowable future to the unknown and the new. This new way of orientating ourselves to the evolution of women's rights offers one means of rethinking the impasse of this area in the present. A more radical evolution is not guaranteed by such, but new conceptual possibilities emerge and offer new ways of thinking in a moment when discussion on sex, gender and sexuality is changing in international human rights law to include issues and identities beyond the remit of the 1980s-90s women's rights campaign alone. This approach not only retains a use for rights by those already engaged with international human rights law - women's rights scholars and non-governmental organisations, for example - it also holds possibility to open up this form of law to those not previously engaged with it. Thought in an untimely manner, this discourse may become amenable to others interested in sex/gender who have viewed these rights as unhospitable to the kind of debate, discussion and social change they wish to stimulate. Of course, women's rights is just one field where untimely evolution may be employed to useful ends, many others may be explored. The above demonstrates how untimeliness may assist in breaking through the kind of impasses which international human rights law is experiencing, offering creative new pathways for the future of this discourse and its possibility - although, as above, never certainty - to facilitate radical social change in the present.

\section{CONCLUSION}

The question of whether international human rights law is out of time, no longer a discourse capable of meaningfully addressing contemporary problems, is one which it is not possible to avoid as a scholar, practitioner or student of law. However, it is possible to respond to this 
question in a new way. As the discussion above has demonstrated, international human rights law can be considered out of time, but not in the sense that a future for such is prohibited. I have proposed that a new future for this discourse can be perceived by returning to the multiple temporalities it contains and exploiting these to consider human rights in international law beyond linearity, progression and predictability. International human rights are out of time in that they can be usefully perceived as untimely; out-of-step concepts that start and stop, that are unpredictable, open to surprise, that exist through endless variation and contingent modification, and that hold potential to connect us with an unknown futurity that does not follow progressively from the past but foregrounds the social as an endless becoming open to transformation and variation. This offers a conceptual framework which has not yet been fully explored by critical literature seeking to reimagine rights in the present, including in futural terms (Douzinas, 2000; Baxi, 2000).

The insights of Grosz, Cornell and Butler offer a productive starting point for this untimely conception of international human rights law and how it might be tangibly engaged to better stimulate radical social change. These authors can be employed to stress the need for lawyers, scholars and practitioners to act in this area of law in the present for an uncertain and uncontrollable future and to use the futurity of rights to characterise everyday life, concepts and ideas as equally uncertain and open to the new. In the spirit of the theoretical tools and reflections above, such activity must be perceived as a modification of how this area of law is traditionally understood. This is not a beginning nor an ending for rights and their temporality, but part of the ongoing, uncontainable descent with modification that drives international human rights law and offers it ongoing utility and possibility. Ongoing work must be undertaken to consider more of what embrace of untimeliness in international human rights law would mean and what the future of this discourse would look like as uncontainable, unknowable and non-linear, committed to opening radical democratic debate on the new and that which is presently excluded. While untimeliness of course poses a risk - what if the new is less than radical? What if attention to new voices, perspectives and discourses does not equate to successful change in particular historic contexts? - this risk is no larger than that posed by continuing to conceive of rights in linear, progressive and predictable terms. Only by rendering rights out of time will international human rights law have any chance of re-emerging as anything more than a marginal and politically blunt discourse in today's time. 


\section{REFERENCES}

Ahmed, Sara (2002) This Other and Other Others. Economy and Society 31(4): 558-572.

Arnhart, Larry (1984) Darwin, Aristotle and the Biology of Human Rights. Social Science Information 23(3): 493-521.

Balibar, Étienne (2013) On the Politics of Human Rights. Constellations 20(1): 18-26.

Bates, Ed (2010) The Evolution of the European Convention on Human Rights: From its Inception to the Creation of a Permanent Court of Human Rights. Oxford: OUP.

Baxi, Upendra (2008) The Future of Human Rights. $3^{\text {rd }}$ ed, Oxford: OUP.

Beitz, Charles (2009) The Idea of Human Rights. Oxford: OUP.

Benhabib, Seyla with Judith Butler, Drucilla Cornell and Nancy Fraser (1995) Feminist Contentions: A Philosophical Exchange. London: Routledge.

Bloom, Federic (2015) The Law's Clock. Georgetown Law Journal 104(1): 1-56.

Bobbio, Noberto (1996) The Age of Rights. Trans. Allan Cameron, Cambridge: Polity.

Bryson, Valerie (2007) Gender and the Politics of Time: Feminist Theory and Contemporary Debates. Bristol: Policy Press.

Bunch, Charlotte (1990) Women's Rights as Human Rights: Toward a Re-Vision of Human Rights. Human Rights Quarterly 12(4): 486-498.

Bunch, Charlotte and Susana Fried (1996) Beijing '95: Moving Women's Human Rights from Margin to Center. Signs 22(2): 200-204.

Burke, Roland (2010) Decolonization and the Evolution of International Human Rights. Philadelphia: University of Pennsylvania Press.

Butler, Judith (1997) The Psychic Life of Power: Theories in Subjection. Palo Alto: Stanford UP.

Butler, Judith (2004) Undoing Gender. London: Routledge.

Butler, Judith (1990) Gender Trouble: Feminism and the Subversion of Identity. London: Routledge.

Butler, Judith, Ernesto Laclau and Slavoj Žižek (2000) Contingency, Hegemony, Universality: Contemporary Dialogues on the Left. London: Verso.

Buyse, Antoine and Michael Hamilton (eds) (2011) Transitional Jurisprudence and the ECHR. Cambridge: CUP.

Case, Mary Ann (2011) After Gender the Destruction of Man? The Vatican's Nightmare Vision of the 'Gender Agenda' for Law. Pace Law Review 31(3): 802-817.

Chambers, Samuel (2004) Giving Up (On) Rights? The Future of Rights and the Project of Radical Democracy. American Journal of Political Science 48(2): 185-200. 
Charlesworth, Hilary (1995) Human Rights as Men's Rights. In Julie Peters and Andrea Wolper (eds) Women's Rights, Human Rights: International Feminist Perspectives. London: Routledge, pp. 103-113.

Charlesworth, Hilary Christine Chinkin and Shelley Wright (1991) Feminist Approaches to International Law. American Journal of International Law 85(4): 613-645.

Cheah, Pheng, Elizabeth Grosz, Judith Butler and Drucilla Cornell (1998) The Future of Sexual Difference: An Interview with Judith Butler and Drucilla Cornell. Diacritics 28(1): 19-42.

Chinkin, Christine (1999) A Critique of the Public/Private Dimension. European Journal of International Law 10(2): 387-395.

Collins, Cath (2010) Post-Transitional Justice: Human Rights Trials in Chile and El Salvador. Philadelphia: University of Pennsylvania Press.

Cook, Rebecca (1993) Women's International Human Rights Law: The Way Forward. Human Rights Quarterly 15(2): 230-261.

Cornell, Drucilla (1993) Transformations: Recollective Imagination and Sexual Difference. London: Routledge.

Cornell, Drucilla (1995) The Imaginary Domain: Abortion, Pornography and Sexual Harassment. London: Routledge.

Cornell, Drucilla (1999) Beyond Accommodation: Ethical Feminism, Deconstruction, and the Law. Washington DC: Rowman and Littlefield.

Darwin, Charles (1892) Journal of Researches into the Natural History and Geology of the Countries Visited During the Voyage of H.M.S. Beagle. London: Ward, Lock, Bowden.

Darwin, Charles (1901) The Descent of Man and Selection in Relation to Sex Volumes 1-2. London: John Murray.

Darwin, Charles (1909) The Origin of Species. New York: PF Collier and Son.

de Sousa Santos, Boaventura (1997) Toward a Multicultural Conception of Human Rights. The German Journal of Law and Society 18(1): 1-15.

Derrida, Jacques (1976) Of Grammatology. Trans. Gayatri Chakrovorty Spivak, Washington DC: John Hopkins UP.

Douzinas, Costas (2000) The End of Human Rights: Critical Thought at the Turn of the Century. Oxford: Hart.

Douzinas, Costas (2007) Human Rights and Empire: The Political Philosophy of Cosmopolitanism. London: Routledge.

Forman, Frieda and Caoran Sowton (eds) (1989) Taking Our Time: Feminist Perspectives on Temporality. Oxford: Pergamon Press. 
French, Rebecca (2001) Time in Law. University of Colorado Law Review 72(3): 663-748.

Grabham, Emily (2016) Brewing Legal Times: Things, Form and the Enactment of Law. Toronto: University of Toronto Press.

Griffin, James (2008) On Human Rights. Oxford: OUP.

Grosz, Elizabeth (2002) Feminist Futures. Tulsa Studies in Women's Literature 21(1): 13-20.

Grosz, Elizabeth (2004) The Nick of Time: Politics, Evolution and the Untimely. Durham: Duke UP.

Grosz, Elizabeth (2005) Time Travels: Feminism, Nature, Power. Durham: Duke UP.

Grosz, Elizabeth (2010) The Untimeliness of Feminist Theory. NORA 18(1): 48-51.

Greenhouse, Carol (1989) Just in Time: Temporality and the Cultural Legitimation of Law. The Yale Law Journal 98(8): 1631-1651.

Hawkins, Mike (1997) Social Darwinism in European and American Thought, 1860-1945: Nature as Model and Nature as Threat. Cambridge: CUP.

Hellum, Anne (2017) (ed) Human Rights, Sexual Orientation and Gender Identity. London: Routledge. Henkin, Louis (1990) The Age of Rights. New York: Columbia UP.

Holtmaat, Rikki and Paul Post (2015) Enhancing LGBTI Rights by Changing the Interpretation of the Convention on the Elimination of All Forms of Discrimination Against Women? Nordic Journal of Human Rights 33(4): 319-336.

Hopgood, Stephen (2013) The Endtimes of Human Rights. Ithaca: Cornell UP.

Howard, Jonathan (2001) Darwin: A Very Short Introduction. Oxford: OUP.

Huyssen, Andreas (2011) International Human Rights and the Politics of Memory: Limits and Challenges. Criticism 54(4): 607-624.

Irigaray, Luce (1985) This Sex Which is Not One. Trans. Catherine Porter with Carolyn Burke, Ithaca: Cornell UP.

Ishay, Micheline (2004) The History of Human Rights: From Ancient Times to the Globalization Era. Berkeley: University of California Press.

Johns, Fleur (2016) The Temporal Rivalries of Human Rights. Indiana Journal of Global Legal Studies 23(1): 39-60.

Kapur, Ratna (2018) Gender, Alterity and Human Rights: Freedom in a Fishbowl. Cheltenham: Edward Elgar.

Khan, Liaquat Ali (2009) Temporality of Law. McGeorge Law Review 40(1): 55-106.

Kristeva, Julia (1981) Women's Time. Signs 7(1): 13-35.

Laclau, Ernesto and Chantal Mouffe (2001) Hegemony and Socialist Strategy: Towards A Radical Democratic Politics, $2^{\text {nd }}$ ed. London: Verso.

Langlois, Anthony (2004) The Elusive Ontology of Human Rights. Global Society 18(3): 243-261. 
Lauren, Paul Gordon (2011) The Evolution of International Human Rights: Visions Seen. $3^{\text {rd }}$ ed, Philadelphia: University of Pennsylvania Press.

Lefort, Claude (1986) The Political Forms of Modern Society. Cambridge, MA: MIT Press.

Levy, Daniel and Natan Sznaider (2010) Human Rights and Memory. Philadelphia: University of Pennsylvania Press.

McCrudden, Christopher (2015) Human Rights Histories. Oxford Journal of Legal Studies 35(1): 179212.

McNeilly, Kathryn (2016) After the Critique of Rights: For a Radical Democratic Theory and Practice of Human Rights. Law and Critique 27(3): 269.-288

McNeilly, Kathryn (2017) Human Rights and Radical Social Transformation: Futurity, Alterity, Power. London: Routledge.

Meister, Robert (2011) After Evil: A Politics of Human Rights. New York: Columbia UP.

Melissaris, Emmanuel (2005) The Chronology of the Legal. McGill Law Journal 50: 839-861.

Moyn, Samuel (2014) Human Rights and the Uses of History. London: Verso.

Moyn, Samuel (2018) Not Enough: Human Rights in an Unequal World. Cambridge: Harvard UP.

Morsink, Johannes (1999) The Universal Declaration of Human Rights: Origins, Drafting and Intent. Philadelphia: University of Pennsylvania Press.

Mutua, Makau (2015) Is the Age of Human Rights Over?' In Sophia McClennen and Alexandra Schultheis Moore (eds) Routledge Companion to Literature and Human Rights. London: Routledge, pp. 450-458.

Otto, Dianne (2015) Queering Gender [Identity] in International Law. Nordic Journal of Human Rights 33(4): 299-318.

Otto, Dianne (2018) (ed) Queering International Law: Possibilities, Alliances, Complicities, Risks. London: Routledge.

Posner, Eric (2014) The Twilight of Human Rights Law. Oxford: OUP.

Rancière, Jacques (2004) Who is the Subject of the Rights of Man? The South Atlantic Quarterly 103(2/3): 297-310.

Rawls, John (2002) The Law of Peoples. $4^{\text {th }}$ ed, Cambridge: Harvard UP.

Raz, Joseph (2010) Human Rights without Foundations. In Samantha Besson and John Tasioulas (eds) The Philosophy of International Law. Oxford: OUP, pp. 339-355.

Robinson, Chris (2013) Biological Foundations of Human Rights. In Dinah Shelton (ed) The Oxford Handbook of International Human Rights Law. Oxford: OUP, pp. 54-81.

Rosenblum, Daren (2011) Unsex CEDAW, Or What's Wrong with Women's Rights. Columbia Journal of Gender and Law 20(2): 98-194. 
Sayers, Janet (1982) Biological Politics: Feminist and Anti-Feminist Perspectives. London: Tavistock.

Stamos, David (2016) The Myth of Universal Human Rights: Its Origin, History, and Explanation, Along with a More Humane Way. London: Routledge.

Tasioulas, John (2012) Towards a Philosophy of Human Rights. Current Legal Problems 65: 1-30.

Tur, Richard (2002) Time and Law. Oxford Journal of Legal Studies 22(3): 463-488.

Vincent, Andrew (2010) The Politics of Human Rights. Oxford: OUP.

Winstanley, Gerrard (2009) The Complete Works of Gerrard Winstanley: Volume 1. Trans. N. Corns, A. Hughes and D. Loewenstein (eds). Oxford: OUP.

\footnotetext{
${ }^{1}$ Here I am extending the themes of a recent monograph (McNeilly, 2017) drawing from new theoretical tools. Namely, the writings of Elizabeth Grosz.

2 The same has also been observed in domestic law (Melissaris, 2005: 843).

${ }^{3}$ Feminist thought is closely connected with the theme of temporality (Kristeva, 1981; Forman and Sowton, 1989; Ahmed, 2002; Bryson, 2007).

${ }^{4}$ See Cheah, Grosz, Butler and Cornell (1998).

${ }^{5}$ Grosz also draws upon other theoretical influences in this project, however. These include Gilles Deleuze, Jacques Derrida and Luce Irigaray.

${ }^{6}$ This must not be thought to eradicate any conception of agency, but does suggest an agent who is nonsovereign (for example, Butler, 1997).

${ }^{7}$ For more on the implications of Grosz's thinking for law see her discussion of justice (2005: 55-89).

${ }^{8}$ Although Butler's thinking on sex/gender will inform discussion of women's rights below.

${ }^{9}$ While some similarity is detectable between Butler and Cornell's approaches, the two cannot be reduced to the same. Butler sees future opening as attached to a conception of gender rather than sexual difference, viewing the former as offering possibility to envisage sexed and gendered life in a multiplicity of forms as opposed to relying on the binary of sexual difference demonstrable in Cornell's thinking (Butler, 2004: 197). See further Benhabib with Butler, Cornell and Fraser (1995).

${ }^{10}$ For earlier feminist work on Darwin see Sayers (1982).

${ }^{11}$ While Darwin's work remains absent from accounts of the development of human rights, it has been engaged in exploration of the underpinnings of universal human rights and natural rights (Arnhart, 1984; Vincent, 2010: 78-84; Robinson, 2013: 54-81; Stamos, 2016: 36-45).

12 This includes CEDAW, the UN Special Rapporteur on Violence Against Women, and the Human Rights Council Working Group on discrimination against women. UN Charter-body and Treaty-body monitoring work has also been attentive to the experiences of women and girls.

${ }^{13}$ For example, the Vatican has sought to advance an approach to 'gender' in a less than radical way (Case, 2011).
} 